\title{
Climacteric Symptoms and Sexual Dysfunction: Association between the Blatt-Kupperman Index and the Female Sexual Function Index
}

\section{Sintomatologia climatérica e disfunção sexual: associação entre o índice de Kupperman e Blatt e o índice de função sexual feminina}

\author{
Emanuela Fonseca Cruz ${ }^{1}$ Vinícius José da Silva Nina ${ }^{2}$ Eduardo Durans Figuerêdo ${ }^{1}$ \\ 1 Universidade Ceuma - Campus Renascença, São Luiz, MA, Brazil \\ 2 Universidade Federal do Maranhão, São Luiz, MA, Brazil \\ Address for correspondence Eduardo Durans Figuerêdo, PhD, Rua \\ Josué Montello, $n^{\circ}$ 1, Renascença II 65075-120 - São Luís-MA, Brazil \\ (e-mail: edufigueredo@terra.com.br).
}

Rev Bras Ginecol Obstet 2017;39:66-71.

\begin{abstract}
Keywords

- climacteric

- sexual dysfunction

- hypoestrogenism

- menopause

- women's health

Objective To investigate the association between the intensity of climacteric symptoms and sexual dysfunction in women aged 40 to 65 years.

Methods Observational, analytic, cross-sectional study conducted with 63 women aged 40 to 65 treated at the gynecology outpatient clinic of a public hospital in northeastern Brazil. A questionnaire was used to collect identification data, clinical information, gynecological-obstetric data, lifestyle traits and information on chronic diseases. Climacteric symptoms and sexual function were evaluated by means of the Blatt-Kupperman index and the Female Sexual Function Index (FSFI) respectively. The association between the two indices was investigated using the chi-squared test; the difference in mean scores on the FSFI as a function of menopausal status was evaluated by Student's t-test. The significance level was set to $p<0.05$.

Results The mean value of the Blatt-Kupperman index was 26.42 (standard deviation [SD]: 4.52 ); $36.51 \%$ of the women exhibited severe symptoms. The mean score on the FSFI was 21.84 (SD: 4.11). More than half of the analyzed women (58.73\%) exhibited sexual dysfunction (FSFI $\leq 26.5$ ). Regarding the association between the BlattKupperman index and the FSFI, the greater the intensity of the climacteric symptoms (Blatt-Kupperman), the higher the frequency of sexual dysfunction (FSFI). Sexual dysfunction was exhibited by $100 \%$ of the participants with severe climacteric symptoms, $70.59 \%$ of those with moderate symptoms, and only $9.09 \%$ with mild symptoms $(p<0.001)$.

Conclusions The application of the Blatt-Kupperman index and of the FSFI allowed the detection of an association between the severity of climacteric symptoms and the prevalence of sexual dysfunction.
\end{abstract}

received

February 5, 2016

accepted

November 21, 2016

published online

March 3, 2017
DOI http://dx.doi.org/

10.1055/s-0037-1598603.

ISSN $0100-7203$.
Copyright @ 2017 by Thieme-Revinter

Publicações Ltda, Rio de Janeiro, Brazil

License terms

c) $(1) \$$ 
Resumo

\section{Palavras-chave \\ - climatério \\ - disfunção sexual \\ - hipoestrogenismo \\ - menopausa \\ - saúde da mulher}

Objetivo Verificar, em mulheres de 40 a 65 anos, a associação entre a intensidade dos sintomas climatéricos e a disfunção sexual.

Métodos Estudo observacional, analítico, transversal, com amostra de 63 mulheres entre 40 e 65 anos atendidas em um ambulatório de ginecologia de um hospital público do Nordeste do Brasil. Foi aplicado um questionário com dados de identificação, informações clínicas, dados ginecológico-obstétricos, hábitos de vida e doenças crônicas. Os sintomas climatéricos e a função sexual foram avaliados utilizando o índice de Kupperman e Blatt e o índice de função sexual feminina (IFSF) respectivamente. Para avaliar a associação entre estes índices, foi utilizado o teste do qui-quadrado, e, para avaliar a diferença entre as médias do IFSF de acordo com o status menopausal, foi utilizado o teste $t$ de Student. Um valor de $p<0,05$ foi considerado significante.

Resultados A média do índice de Kurpperman e Blatt da população estudada foi de 26,42 (desvio-padrão [DP]: 4,52). Houve presença de sintomas acentuados em $36,51 \%$ das mulheres estudadas. A média do IFSF entre as pacientes estudadas foi de 21,84 (DP: 4,11). Mais da metade das mulheres em estudo $(58,73 \%)$ apresentou disfunção sexual (FSFI $\leq 26,5)$. Quando analisada a associação entre o índice de Kupperman e Blatt e o IFSF, foi observado que, quanto maior a intensidade dos sintomas climatéricos (Kupperman e Blatt), maior a frequência de disfunção sexual (IFSF). Apresentaram disfunção sexual $100 \%$ das pacientes com sintomas climatéricos acentuados, sendo que 70,59\% com sintomas moderados, e apenas $9,09 \%$ com sintomas leves $(p<0,001)$.

Conclusões No presente estudo, quando aplicados o índicesde Kupperman e Blatte o IFSF, observou-se associação entre a gravidade dos sintomas climatéricos e a prevalência de disfunção sexual.

\section{Introduction}

The climacteric is a period characterized by a physiological state of progressive hypoestrogenism; it begins at approximately age 40 , and extends until age 65 , marking the transition from the reproductive phase to the non-reproductive state. ${ }^{1,2}$ The hormonal changes related to the climacteric are perceptible due to the state of hypoestrogenism, which is accompanied by a characteristic set of symptoms, including hot flashes, paresthesia, joint pain, muscle pain, headache, night sweats, vaginal dryness, weakening of the pelvic floor muscles, dyspareunia, insomnia and mood disorders. ${ }^{3,4}$ After menopause, the epithelium of the genital tract becomes thinner, the secretions of the sudoriferous and sebaceous glands of the vulva decrease, the Bartholin's glands atrophy, lubrication decreases, and the vagina becomes narrower, with consequent reduction of its rugae and elasticity. ${ }^{5}$

Cabral et $\mathrm{al}^{3}$ found an inverse correlation between sexual function and climacteric symptoms. Upon analyzing each of the phases of the sexual response separately, they found that the factors that most contributed to the low scores exhibited by the women with high risk of sexual dysfunction were arousal, orgasm and pain. In another study, Valadares et $\mathrm{al}^{6}$ detected sexual dysfunction in climacteric women. They concluded that being 50 years of age or older; going through the menopausal transition or postmenopause; not having a sexual partner; reporting hot flashes, insomnia, depression, nervousness, sedentary lifestyle, arterial hypertension, or urinary incontinence; and poor self-perception of health were significantly associated with a below median sexuality score. From the cultural perspective, menopause is a symbol of aging and decrepitude; its occurrence might result in poorer self-esteem and loss of sexual desire. ${ }^{7-9}$ In their study with 370 climacteric women from Natal, Rio Grande do Norte, Brazil, Cabral et $\mathrm{al}^{3}$ found an association between the climacteric symptoms and the worsening of sexual dysfunction.

Despite the relevance of this subject, few studies have investigated the specific aspects of sexual function during the climacteric. More thorough knowledge of this problem will lead to better care for menopausal women, improving their quality of life.

The aim of the present study was to investigate the relationship between the intensity of climacteric symptoms and sexual dysfunction in women aged 40 to 65 years. The Blatt-Kupperman index was used to assess the intensity of the climacteric syndrome, and the Female Sexual Function Index (FSFI) was used as a predictor of sexual dysfunction in this population. 


\section{Methods}

The present observational, analytic and cross-sectional study was conducted with a sample comprising 63 women aged 40 to 65 treated at the gynecology outpatient clinic of a public hospital in Brazil. Data were collected from May to September 2015.

All the women aged 40 to 65 years old who spontaneously sought care at the gynecology outpatient clinic and were not taking hormone replacement therapy were invited to participate in the study. Explicit refusal, inability to participate and the presence of any factor hindering the performance of interviews (for instance, a psychiatric disease) were considered exclusion criteria, as was the use of neuroleptics, anxiolytics or antidepressants, as sexual dysfunction is one of the main side effects of these drugs. ${ }^{10}$

Women waiting for medical consultation were randomly selected and individually invited to participate. After the details of the study were explained, the women who agreed to participate signed an informed consent form and were sent to a private room to be individually interviewed by the investigator.

A protocol form was filled out first, which contained identification data and clinical information. The following data were collected: age, skin color, civil status, educational level, income and occupation. The clinical information was evaluated based on gynecological-obstetric data, lifestyle and the presence of chronic diseases.

Next, the participants verbally answered the questions included in the instruments for assessing climacteric symptoms and sexual function. The climacteric symptoms were evaluated based on the Blatt-Kupperman index, which measures the intensity of several symptoms as reported by the respondent. Symptom severity is considered mild when the score is equal to or lower than 19; moderate, from 20 to 35; and severe, above $35 .{ }^{11}$

The symptoms included are hot flashes, paresthesia, insomnia, nervousness, depression, fatigue, arthralgia/myalgia, headache, palpitations and tingling.

The participants' sexual function was evaluated using the FSFI, which is a high-quality instrument recommended for use with women. ${ }^{12}$ The FSFI was translated and validated for use with Portuguese-speaking populations. It assesses key dimensions of female sexual function in the previous four weeks. It comprises 19 questions divided into 5 domains of the sexual response: desire, arousal, lubrication, orgasm satisfaction and vaginal pain or discomfort. Scores equal to or lower than 26.5 are considered to represent high risk of sexual dysfunction. ${ }^{13,14}$

Following the data collection, an exploratory analysis was performed, in which the sample was described as to its sociodemographic, clinical, gynecological-obstetrical and behavioral characteristics. The mean and standard error of the FSFI domain scores were calculated according to the categorization of risk of sexual dysfunction as positive (FSFI $\leq 26.5$ ) or negative. The climacteric symptoms (Blatt-Kupperman index) were categorized on an ordinal scale according to their intensity (mild, moderate or severe). ${ }^{13,14}$
The association between the intensity of the climacteric symptoms and the presence of sexual dysfunction was assessed by the chi-squared test. The difference between FSFI mean values according to the menopausal status was evaluated using Student's $t$-test. The analyses were performed with Stata $12^{\circledR}$ (StataCorp, College Station, TX, USA). The study was approved by the institutional research ethics committee under ruling no. 37810214.7.0000.5084.

\section{Results}

A total of 63 women aged 40 to 65 were analyzed; their mean age was 51.44 years (standard deviation [SD]: 7.24). Thirteen (20.6\%) women were premenopausal, and 50 (79.4\%) were postmenopausal. Most had brown skin (53.97\%), were single (69.84\%), had completed secondary education (26.98\%), and had no monthly income (50.73\%). The demographic profile of the sample is described in - Table $\mathbf{1}$.

Regarding lifestyle, 3 women (4.76\%) were smokers, and only 1 consumed alcohol (1.6\%). Nine (14.29\%) women did not have a stable partner, and 54 (85.71\%) had a single partner. Regarding the number of pregnancies, $14.29 \%$ of the women were nulliparous, and $73.02 \%$ were multiparous. Fifty-three $(84.13 \%)$ women did not have a history of abortion. A total of $36.51 \%$ of the participants had hypertension, and $11.11 \%$ had diabetes (-Table 1).

The mean Blatt-Kupperman index score was 24.42 (SD: 4.52). Severe climacteric symptoms were presented by 23 (36.51\%) women. The distribution of the participants according to the Blatt-Kupperman index score is described in -Table 1.

The total FSFI score was 21.84 (SD: 4.11 ), and 37 (58.73\%) women had FSFI $\leq 26.5$. The proportion of subjects according to the total FSFI score is described in -Table 1.

Premenopausal women had higher total FSFI scores then postmenopausal women (respectively, a total FSFI of 26.64 [SD: 5.15] versus A total FSFI of 20.34 [SD: 4.02], $p=0.01$ ).

There was an association between the Blatt-Kupperman index and the FSFI total score $\leq 26.5(p<0.01)$.

All 23 women with severe climacteric symptoms exhibited total FSFI scores $\leq 26.5$. Among the 17 participants with moderate symptoms, 12 (70.59\%) had total FSFI scores $\leq 26.5$. Among the 22 participants with mild symptoms, $2(9.09 \%)$ had total FSFI scores $\leq 26.5$ ( $p<0.001)$. The analysis of the association between the Blatt-Kupperman index and the FSFI is described in - Table 2.

\section{Discussion}

The prevalence of sexual dysfunction found in the study population was similar to the prevalence previously reported for the Northeastern, Midwestern, Southern and Southeastern regions of Brazil (50 to 67\%). ${ }^{3,15-17}$ These data might indicate that climacteric symptoms influence female sexual function at this stage of life, significantly increasing the occurrence of sexual dysfunction. Cabral et $\mathrm{al}^{3}$ investigated sexual dysfunction in climacteric women, and found that the typical symptoms associated with this stage influenced the 
Table 1 Sociodemographic and clinical characteristics of climacteric women $(n=63)$

\begin{tabular}{|c|c|}
\hline Variable & Proportion n (\%) \\
\hline \multicolumn{2}{|l|}{ Skin color/ethnicity } \\
\hline White & $21(33.33)$ \\
\hline Brown & $34(53.97)$ \\
\hline Black & $8(12.70)$ \\
\hline \multicolumn{2}{|l|}{ Marital status } \\
\hline Single & $44(69.84)$ \\
\hline Married & $12(19.05)$ \\
\hline Widowed & $05(7.94)$ \\
\hline Divorced & $02(3.17)$ \\
\hline \multicolumn{2}{|l|}{ Educational level } \\
\hline Incomplete primary education & $15(23.81)$ \\
\hline Complete primary education & $12(19.05)$ \\
\hline Incomplete secondary education & $17(26.98)$ \\
\hline Complete secondary education & $10(15.87)$ \\
\hline Higher education & 09 (14.29) \\
\hline \multicolumn{2}{|l|}{ Monthly income } \\
\hline None & $36(57.14)$ \\
\hline Minimum wage & $16(25.40)$ \\
\hline 2 minimum wage equivalents & $06(9.52)$ \\
\hline 3 minimum wage equivalents & 01 (1.59) \\
\hline 4 minimum wage equivalents & 01 (1.59) \\
\hline No fixed income & $03(4.76)$ \\
\hline Premenopause & $13(40.86)$ \\
\hline Postmenopause & $50(55.14)$ \\
\hline 0 pregnancy & 09 (14.29) \\
\hline 1 pregnancy & $08(12.70)$ \\
\hline$\geq 1$ pregnancy & $46(73.02)$ \\
\hline Nulliparous & $13(20.63)$ \\
\hline Primiparous & $06(9.52)$ \\
\hline Multiparous & $44(69.84)$ \\
\hline 0 abortions & $53(84.13)$ \\
\hline 1-3 abortions & $06(9.52)$ \\
\hline Diabetes & $07(11.11)$ \\
\hline Hypertension & $23(36.51)$ \\
\hline Smoking & $03(4.76)$ \\
\hline \multicolumn{2}{|l|}{ Climacteric symptoms } \\
\hline None & $01(1.59)$ \\
\hline Mild & $22(34.92)$ \\
\hline Moderate & $17(26.98)$ \\
\hline Severe & $23(36.51)$ \\
\hline \multicolumn{2}{|l|}{ FSFI total score } \\
\hline FSFI score $>26.5$ & $26(41.27)$ \\
\hline FSFI score $\leq 26.5$ & $37(58.73)$ \\
\hline
\end{tabular}

Abbreviation: FSFI, Female Sexual Function Index. quality of life of the participants, as sexual satisfaction is a significant marker of well-being. Therefore, the impairment of sexual function affects the quality of life of women.

In the present study, all the women with high scores on the Blatt-Kupperman index exhibited sexual dysfunction (FSFI $\leq 26.5$ ). Among those with moderate symptom severity (Blatt-Kupperman index), 70.59\% had sexual dysfunction according to the FSFI score. Similar results were also found in other studies, with the rate of sexual dysfunction varying from $51 \%$ to $75 \%$ among climacteric women. ${ }^{6,18-20}$ Finally, $90.91 \%$ of the women with mild climacteric symptoms did not exhibit sexual dysfunction. These findings are explained by the symptomatology of the climacteric syndrome, as several physical (hot flashes, vasomotor symptoms) and mental (emotional dysfunction, mood disorders) symptoms contribute to sexual dysfunction.

Cabral et $\mathrm{al}^{3}$ found a significant inverse correlation between the climacteric symptoms and the sexual function, that is, the women with more climacteric symptoms were at higher risk for sexual dysfunction. Valadares et $\mathrm{al}^{6}$ detected a significant occurrence of sexual dysfunction among middleaged women. A previous study conducted in Rio Grande do Sul, Brazil, found a reduction of sexual activity after menopause and an association between climacteric symptoms and sexual dysfunction, ${ }^{15}$ which agrees with the results of the present study. In their study of middle-aged women in Ecuador, Chedraui et $\mathrm{al}^{20}$ also identified an inverse correlation between the intensity of the climacteric symptoms and the sexual function. Mezones-Holguin et $\mathrm{al}^{21}$ applied the FSFI in a study with climacteric women in Peru, and found a significant association of sexual dysfunction with depression and also with low educational levels. De Lorenzi et $\mathrm{al}^{22}$ found that the women with lower education levels, those who described themselves as not white, and those with lower per capita household income exhibited significantly more intense climacteric symptoms. Valadares et $\mathrm{al}^{6}$ observed that as chronological age increases, sexual function declines among climacteric women. Ford et $\mathrm{al}^{23}$ reported that an increase in age is associated with poorer sexual function, thus agreeing with the results of the present study. Dennerstein et $\mathrm{al}^{24,25}$ showed that the proportion of women with sexual dysfunction gradually increases from the beginning to the last phase of the menopausal transition. In a study in Chile, Castelo-Branco et $\mathrm{al}^{26}$ found that $51.3 \%$ of the sexually active women exhibited sexual dysfunction, and that the latter increased with age. The results of these two studies corroborate the present study, in which sexual dysfunction prevailed among the menopausal (older) women compared with the premenopausal (younger) women. In the study by Mishra and Kuh, ${ }^{27}$ somatic symptoms and hot flashes/cold sweats were associated with difficulties with intercourse, while psychological symptoms, stressful lives and increasing age were associated with a decline in sex life. These findings agree with the present study, in which the intensity of climacteric symptoms was associated with the presence of sexual dysfunction. In the present study, $36.51 \%$ of the participants had hypertension, and $11.11 \%$ had diabetes. Although none of these comorbidities were associated with 
Table 2 Association between the Blatt-Kupperman index and the FSFI in climacteric women $(n=63)$

\begin{tabular}{|l|l|l|l|l|l|}
\hline FSFI score & \multicolumn{4}{|l|}{ Climacteric symptoms } & Total \\
\hline & No symptoms & Mild & Moderate & Severe & \\
\hline$>26.5$ & $1(100)^{*}$ & $20(90.91)^{*}$ & $05(29.41)^{*}$ & $0(0)^{*}$ & $26(24.27)$ \\
\hline$\leq 26.5$ & $0(0)^{*}$ & $2(9.09)^{*}$ & $12(70.59)^{*}$ & $23(100)^{*}$ & $37(58.73)$ \\
\hline Total & $1(100)$ & $22(100)$ & $17(100)$ & $23(100)$ & $63(100)$ \\
\hline
\end{tabular}

Abbreviation: FSFI, Female Sexual Function Index.

Note: ${ }^{*}$ Chi-squared test; $p<0.001$.

climacteric symptoms or sexual dysfunction, previous studies found that both influence sexual function negatively. ${ }^{28-30}$

Overall, the severity of the climacteric symptoms in the analyzed sample was moderate (26.42), as $98.41 \%$ of the participants scored above 0 on the Blatt-Kupperman index. In a study conducted in China by Tao et $\mathrm{al}^{31}$ with 277 women, most of the participants had high scores on the BlattKupperman index, confirming the efficacy of this scale. The mean total FSFI score in the present study was 21.84 , and in a similar population assessed by Cabral et $\mathrm{al}^{3}{ }^{3}$ it was 12.71 ; those values indicate that both samples exhibited sexual dysfunction.

The results of the present study should be interpreted cautiously, given the study's limitations: the sexual dysfunction was assessed based on the participants' self-report, and female aging is accompanied by signs and symptoms of its own, which, added to biopsychosocial factors, interfere with the women's sexual function. Nevertheless, our results indicate a positive association between the intensity of the climacteric symptoms (Blatt-Kupperman) and the prevalence of sexual dysfunction (FSFI). The rise in the prevalence of sexual dysfunction in menopause suggests the need for doctors to pay attention to the sexual sphere at each gynecological visit; the climacteric is influenced by a culture characterized by prejudice against women, fear and myths, and as a function of educational factors, many women are led to experience sexual intercourse in an unsatisfactory way at this stage of life. Accurate knowledge of the climacteric as a whole is important for the promotion of a better quality of life for aging women.

\section{References}

1 Sociedade Brasileira de Climatério [Internet]. Consenso brasileiro multidisciplinar de assistência à mulher climatérica. São Paulo: SOBRAC; 2003 [citado 2015 Jun 10]. Disponível em: http://p. download.uol.com.br/menospausa/Consenso\%20-\%20Menopausa. pdf

2 Utian WH. The International Menopause Society menopauserelated terminology definitions. Climacteric 1999;2(04):284-286

3 Cabral PU, Canário AC, Spyrides MH, et al. [Influence of menopausal symptoms on sexual function in middle-aged women]. Rev Bras Ginecol Obstet 2012;34(07):329-334 Portuguese.

4 Ribeiro B, Magalhães AT, Mota I. Disfunção sexual feminina em idade reprodutiva: prevalência e fatores associados. Rev Port Med Geral Fam. 2013;29(01):16-24
5 Lara LA, Useche B, Ferriani RA, et al. The effects of hypoestrogenism on the vaginal wall: interference with the normal sexual response. J Sex Med 2009;6(01):30-39

6 Valadares AL, Pinto-Neto AM, Osis MJ, Conde DM, Sousa MH, Costa-Paiva L. Sexuality in Brazilian women aged 40 to 65 years with 11 years or more of formal education: associated factors. Menopause 2008;15(02):264-269

7 De Lorenzi DRS, Baracat EC. Climatério e qualidade de vida. Femina 2005;33(12):899-903

8 Lopes GP. Sexualidade: fisiopatologia, diagnóstico e tratamento. In: Fernandes CE. organizador. Menopausa: diagnóstico e tratamento. São Paulo: Segmento; 2013. p. 117-24

9 Cavalcanti IF, Farias PD, Ithamar L, Silva VM, Lemos A. [Sexual function and factors associated with sexual dysfunction in climacteric women]. Rev Bras Ginecol Obstet 2014;36(11):497-502 Portuguese

10 Sousa CAC. Antidepressivos e disfunções sexuais. Psychiatry on Line Bras [Internet]. 2012 [citado 2015 Out 25];17(10). Disponível em: http://www.polbr.med.br/ano12/art1012.php

11 Sousa RL, Sousa ESS, Silva JCB, Filizola RG. [Fidedignidade do teste-reteste na aplicação do índice menopausal de Blatt e Kupperman]. Rev Bras Ginecol Obstet 2000;22(08):481-487 Portuguese

12 Rosen R, Brown C, Heiman J, et al. The Female Sexual Function Index (FSFI): a multidimensional self-report instrument for the assessment of female sexual function. J Sex Marital Ther 2000; 26(02):191-208

13 Thiel RdoR, Dambros M, Palma PCR, Thiel M, Riccetto CL, Ramos MdeF. [Translation into Portuguese, cross-national adaptation and validation of the Female Sexual Function Index]. Rev Bras Ginecol Obstet 2008;30(10):504-510 Portuguese.

14 Wiegel M, Meston C, Rosen R. The female sexual function index (FSFI): cross-validation and development of clinical cutoff scores. J Sex Marital Ther 2005;31(01):1-20

15 De Lorenzi DRS, Saciloto B. Factors related to frequency of sexual activity of postmenopausal women. Rev Assoc Med Bras (1992) 2006;52(04):256-260

16 Teles TO, Pereira KF, Sousa VR, Paranaiba JS, Texeira CS. Consequências do climatério e menopausa na sexualidade: um estudo no centro de atendimento integrado a saúde de Rio Verde-Goiás. SaBios Rev Saúde Biol. 2012;7(03):45-51

17 Badran AV, Araujo ALL, Nagae DKI, et al. Aspectos da sexualidade na menopausa. Arq Med Hosp Fac Cienc Med Santa Casa São Paulo. 2007;52(02):39-43

18 Blümel JE, Chedraui P, Baron G, et al; Collaborative Group for Research of the Climacteric in Latin America (REDLINC). A large multinational study of vasomotor symptom prevalence, duration, and impact on quality of life in middle-aged women. Menopause 2011;18(07):778-785

19 Chedraui P, Pérez-López FR, Mezones-Holguin E, San Miguel G, Avila C; Collaborative Group for Research of the Climacteric in Latin America (REDLINC). Assessing predictors of sexual function 
in mid-aged sexually active women. Maturitas 2011;68(04): 387-390

20 Chedraui P, Pérez-López FR, San Miguel G, Avila C. Assessment of sexuality among middle-aged women using the Female Sexual Function Index. Climacteric 2009;12(03):213-221

21 Mezones-Holguin E, Córdova-Marcelo W, Lau-Chu-Fon F, et al. Association between sexual function and depression in sexually active, mid-aged, Peruvian women. Climacteric 2011;14(06): 654-660

22 De Lorenzi DRS, Danelon C, Saciloto B, Padilha Júnior I. [Predicting factors of climacteric symptoms]. Rev Bras Ginecol Obstet 2005; 27(01):7-11 Portuguese.

23 Ford K, Sowers M, Crutchfield M, Wilson A, Jannausch M. A longitudinal study of the predictors of prevalence and severity of symptoms commonly associated with menopause. Menopause 2005;12(03):308-317

24 Dennerstein L, Randolph J, Taffe J, Dudley E, Burger H. Hormones, mood, sexuality, and the menopausal transition. Fertil Steril 2002; 77(Suppl 4):S42-S48

25 Dennerstein L, Guthrie JR, Hayes RD, DeRogatis LR, Lehert P. Sexual function, dysfunction, and sexual distress in a prospective, population-based sample of mid-aged, Australian-born women. J Sex Med 2008;5(10):2291-2299

26 Castelo-Branco C, Blumel JE, Araya H, et al. Prevalence of sexual dysfunction in a cohort of middle-aged women: influences of menopause and hormone replacement therapy. J Obstet Gynaecol 2003;23(04):426-430

27 Mishra G, Kuh D. Sexual functioning throughout menopause: the perceptions of women in a British cohort. Menopause 2006; 13(06):880-890

28 Doumas M, Tsiodras S, Tsakiris A, et al. Female sexual dysfunction in essential hypertension: a common problem being uncovered. J Hypertens 2006;24(12):2387-2392

29 Enzlin P, Mathieu C, Van den Bruel A, Bosteels J, Vanderschueren D, Demyttenaere K. Sexual dysfunction in women with type 1 diabetes: a controlled study. Diabetes Care 2002;25(04):672-677

30 Schiel R, Müller UA. Prevalence of sexual disorders in a selectionfree diabetic population (JEVIN). Diabetes Res Clin Pract 1999; 44(02):115-121

31 Tao M, Shao H, Li C, Teng Y. Correlation between the modified Kupperman Index and the Menopause Rating Scale in Chinese women. Patient Prefer Adherence 2013;7:223-229 